\title{
Inflation and Economic Growth: Evidence from Pakistan
}

\author{
Shahzad Hussain (Corresponding Author) \\ $\mathrm{PhD}$ Candidate, Department of Economics, Bahauddin Zakariya University \\ Multan, Pakistan \\ E-mail: shahzadecon@yahoo.com \\ Shahnawaz Malik \\ Chairman and Professor, Department of Economics \\ Bahauddin Zakariya University, Multan, Pakistan \\ E-mail: shahnawazmalik@bzu.edu.pk
}

Received: March 26, 2011

Accepted: April 7, 2011

doi:10.5539/ijef.v3n5p262

\begin{abstract}
This study empirically explores the nexus between inflation and economic growth in the context of Pakistan economy. Annual data for the period of 1960-2006 has been used. According to the results of the study, inflation is positively related with economic growth in Pakistan and vice versa. As for as, the concern of causality between these two variables, it is found to be uni-directed. In other words, inflation is causing growth but not vice versa. To examine the extent to which economic growth is related to inflation and vice versa, Error Correction Models (ECM) have been employed. With the help of this procedure, it is possible to examine the short-run and long-run relationship between two variables. The Error Correction Model (ECM) test is essential to see whether an economy is converging towards equilibrium in the short- run or not. According to the outcome of the study, inflation is away from its equilibrium value. For instance, the error correction term -0.49 implies that 49 percent of the adjustments towards the short-run equilibrium relation for Pakistan occur within a year through changes in growth rates. On the other hand, 58 percent (error correction term -0.58) of the deviation of the inflation from its short-run equilibrium level is corrected each year. Furthermore, the estimated threshold model suggest that 9 percent threshold level (i.e. structural break point) of inflation above which inflation starts to lower the economic growth in Pakistan. Pakistan must need inflation but in single digit for growth because too fast a growth rate may also accelerate the inflation rate.
\end{abstract}

Keywords: Inflation, Economic Growth, Granger Causality, Error Correction Models, Threshold

JEL Classification: E31, O40, C13, C22

\section{Introduction}

Inflation is a complex economic phenomenon that has still extensive attention of the macroeconomists, policymakers and the central bankers from both developing and developed world. It is also a main subject of the macroeconomics and one of the principal concerns of the policymakers and the public.

As per comprehensive definition we may assert that inflation is a constant rise in commonly accepted price indices (Note 1) on account of which broad spectrum of living cost has mounted up to the level where general public feel relatively poorer. This could be easily stemmed out of this definition that increase in prices should be so constant and permanent that it may be alleged as inflation. There are two major determining factors of inflation: 1) Demand-pull inflation (Note 2): It appears in an economy when aggregate demand is higher than aggregate supply, 2) Cost push inflation: It emerges in an economy as a result of increase in cost of basic inputs of the production process. There are number of factors those affect cost push inflation such as wages, low productivity, erroneous fiscal policy, and imported rising inflation. It is widely accepted that basic factor for increase in inflation has been termed as enhanced level of economic activity in a society. So, strengthening in economic activity leads to high inflation and weak economic activity lowers the inflation. This macroeconomic variable has very much importance in economic literature because it has strong effects on economic stability of the country.

There is no controversy in literature upon association of inflation and economic growth but serious debate arises when we talk about the sign of relationship between the two. Evidence in this regard supports both the signs of relationship either it is negative or positive. The controversy breeds two main school of though in this regard i.e. Structuralists and Monetarists. Structuralists considers inflation as a fundamental element for economic growth of a country while as per Monetarists inflation has an ability to determine economic progress (Malik and Chowdhry, 2001). Mundell (1965) mentioned that inflation causes positive effects on capital formation and capital information has a positive relationship with economic growth. According to the work of Malik and Chowdhury (2001), inflation and growth are positively related in India, Pakistan, Bangladesh and Sri Lanka. However, existence of negative association between inflation and economic growth has also been pointed out in so many other studies (Note 3 ) 
whether the studies have been conducted on time series or cross-sectional data of developed or developing country. After all this controversy leads the theorists upon a consensus that if in a county there is stability in a low level of inflation (may be a single digit inflation) than inflation may prove be helpful in promoting economic growth of that country (Mubarik, 2005). Such an association between the two further depends upon the economic environment of that country and produce different results for different countries. Keeping in view this perspective econometricians introduced a technique to investigate the relationship between inflation and economic growth. As per this technique a verge point regarding inflation has been utilized which differs the effects of inflation on economic growth. Up to that verge point the inflation is helpful to promotes economic growth and beyond that inflation affects economic growth negatively (Sweidan, 2004).

Pakistan experienced uneven growth pattern throughout it history. The average economic growth during last 45 years is around 5.5 percent. Pakistan has been facing lot of problems in macro economic management such as internal and external threats. Internally not only there exists gaps between receipts and public expenditures, savings and investments, population growth and capital formation in Pakistan but success in establishing financial markets has also not been achieved sufficiently. Externally Pakistan has to face imbalance between exports and imports and has to face exchange rate problems. Therefore, it looks impossible to achieve the task of sustainable growth pattern in Pakistan. High inflation rate is also considered as an ill for economic growth in Pakistan because it had witnessed high inflation since its independence. The average inflation rate during last 45 years is around 8 percent.

This study attempts to discover the association existed between inflation and economic growth while taking into consideration the methodology of bi-variate regression (Note 4). Multivariate (Note 5) methodology may cause to create complications in this association (Ghosh and Phillips, 1998) because when we may explore this relationship while using multivariate technique, we have to include some other important variables as determinant. Out of several complications; firstly robustness of our findings may be reduced due to conditioning variables (Note 6), secondly these contingent variables are also depended upon inflation rate. For example we may observe that economic growth depends upon investment and investment itself depends upon inflation. So, these indirect effects can mislead the understandings of inflation-growth relationship. Thirdly, the relationship between inflation and different determinants of economic growth may also be intervened by the presence of certain variables such as effects of inflation on economic growth may be accelerated on account of capital formation in the economy.

This study has the central objective to investigate growth-inflation relationship empirically while focusing Pakistan economy. Second, the study seeks to observe the short-run and long-run effects of inflation on economic growth of Pakistan and vice versa. Thirdly, out of this study may be able to resolve an issue regarding finding out the best level of inflation rate for Pakistan economy. Finally, the study has special purpose to provide an efficient and active policy for future.

The rest of the study is organized as follows. Next section briefly provides the historical trends of inflation and economic growth in Pakistan. Section three briefly reviews the time series and cross-country studies on inflation and growth nexus. Data has been described in section four while the methodological issues and model specification are in section five. In section six, empirical results along with their interpretations are reported. Section seven sums up the study with some policy implications.

\section{Inflation and Economic Growth in Pakistan: A Historical Perspective}

Pakistan may be considered as a growing economy in South Asia. Until 1970s, GDP growth rates of Pakistan were observed to be lower than 5 percent while for the same period, inflation was documented higher than 10 percent. Again the same episode was witnessed in 1990s (Mubarik, 2005). Pakistan experienced an even growth pattern since its independence. On average GDP growth rate was remained at the level of 4 percent in Pakistan. This economy also experienced high inflation and unemployment during most of the period since its inception (Khalid, 2005).

Now, we visually examine the trends of inflation and GDP growth rates in Pakistan. The country experienced the single digit inflation rate during 1960's and also performed very well in terms of growth rate of GDP as illustrated in Fig. 1. GDP growth rate remained below 5\% until late 1970's while during the same period, the country witnessed mostly double digit inflation rate. So, it is a visual evidence that during 1970's, high inflation rate remained detrimental to economic growth. In 1960's, inflation rate remained below $9 \%$ with highest figure of $8.6 \%$ in 1966-67 while a respectable growth rate was observed throughout the decade.

Insert Figure 1, Figure 2 Here

During 1980's, moderate GDP growth rate was observed while the inflation rate also remained single digit except $11.1 \%$ and $10.4 \%$ in 1981-82 and 1988-89 respectively (see Fig. 2). Pakistan has sustained a double-digit inflation between 9.8 to 13.0 percent during the first seven years of the 1990s. GDP growth rate remained unstable during 1990 's and has decreasing trend with some fluctuations. Lowest figure of 1990's was observed in 1996-97 with rate of $1.7 \%$ as compared to highest figure in $1991-92$ with rate of $7.57 \%$. 
Inflation slowed to an average of 5.7\% in the remaining three years of 1990's. Inflation rate decreased sharply just after 1990's and was observed below 5\% except 2004-05 (9.3\%). During the same period GDP growth rate started to increase and the country witnessed the figure of $8.35 \%$ in $2004-05$.

In Fig. 3, we may be able to observe movements in economic growth and inflation in different decades of Pakistan economy during the period 1961-2006. It is a fact that concrete conclusions could not be drawn out of visual examination of Fig. 3 but an inverse relationship between economic growth and inflation rate could easily be inferred throughout the period under study.

Mubarik (2005) also suggests that growth-inflation relationship could be easily understood through portraying their trends over time. Hence, we decomposed the data for the period (1961-2006) within 7 grouped observations. The data of inflation has been selected while utilizing the technique of maxima and minima. If inflation rate is less than or equal to 3 percent, we quantify it by level 3. In the same way if the inflation level is greater than 3 percent but less than or equal to 5 percent, we quantify it by a level of 5 and so on. The process continued till the level 15 i.e. if inflation rate is more than $13 \%$.

\section{Insert Figure 3 Here}

After quantifying inflation we estimate the average level of economic growth for each point of inflation e.g. what is the average GDP growth rate in the whole sample period (1961-2006), if inflation rate is $3 \%$ or less and so on. Figure 4 shows that there is negative relationship between inflation and GDP growth rate up to $7 \%$ level of inflation. From $7 \%$ to $11 \%$ level of inflation, there is positive relationship between inflation and GDP growth rate but after $11 \%$ level of inflation, there is again negative relationship between the two variables. Khan and Senhadji (2001) also concluded that more the $11 \%$ level of inflation is detrimental to economic growth in developing countries. The analysis is different from the analysis of Mubarik (2005). He has found positive relationship up to $7 \%$ level of inflation and beyond that level there is negative relationship. It may be due to change in the sample period. Figure 4 is more precise and accurate picture of the relationship between inflation and GDP growth rate. But it is still unwise to conclude any relationship between the two variables and further investigation is needed here.

\section{Insert Figure 4 Here}

\section{Related Work}

In the history of economic theory there is strong contradiction among economists regarding the sign and strength of relationship between economic growth and inflation. For the last two decades, a number of research studies have focused their attention toward the question exploring this relationship. These studies, either theoretical or empirical, have been conducted not only in developed countries but also in developing countries.

Naqvi and Khan (1989) highlighted some interesting points about inflation and growth in Pakistan. They concluded that Pakistan should keep inflation level at single-digit and maintain a growth rate of GDP in the 6.5 to 7 percent range. They found negative relationship between inflation and economic growth. Possible (adverse) effects of anti-inflationary policies on the growth rate of the economy should also be under concerned. They discussed the causes and consequences of inflation and presented forecasts of inflation within the framework of 83-equations of PIDE Macro-econometric model (1989) (Note 7).

Barro (1995) empirically investigates growth-inflation relationship. For this purpose he used a panel survey focusing 100 countries for thirty years. He utilized different sophisticated statistical and econometric techniques so as to explore this relationship. He reached to the conclusion that there exists a negative relationship between these two variables. However, he also added that it is high enough and long term inflation which cause economic growth to reduce.

Sarel (1995) stated that due to modest inflation rates in most countries before the 1970s, most empirical studies conducted at that time show the evidence of a positive relationship between inflation and economic growth and after that, rates started to be high. So, study concluded with negative relationship between inflation and economic growth.

The hot discussion for the growth-inflation relationship geared up Bruno and Easterly to inquire this relationship with a little bit depth. Bruno and Easterly (1995 and 1996) took into consideration the determinants of economic growth while focusing on those countries where inflation was a serious problem. They select a sample of 26 countries and select the time period from 1961 to 1992. They measured inflation crisis as an inflation rate of 40 percent and higher. They observed an inverse relationship between inflation and economic growth. They also found a trend in the countries to restore their economic growth at a rate where they existed before crisis. Finally, they concluded that there is no association between inflation and economic growth below a 40 percent threshold level of inflation.

De Gregorio (1996) reviewed the theory and evidence on inflation and growth and provided additional empirical evidence on the non-linear relationship for OECD and some developing countries for the period 1960-1985. He found robust negative relationship between inflation and growth. He argued that inflation limits growth mainly by 
reducing the efficiency of investment rather than its level. In another study on OECD countries, Andres and Hernando (1997) reviewed the costs of inflation in the long-run. They concluded that current inflation has never been found to be positively correlated with income per capita in the long-run.

Malla (1997) also conducted the study for OECD countries and some Asian countries separately and found that there is negative and significant relationship between inflation and growth for OECD while insignificant for developing countries of Asia. He also concluded that cross-country analysis has some problems regarding adjustment in country sample and time period. So, the relationship between inflation and growth is inconclusive.

Gosh and Phillips (1998), covering IMF member countries over 1960 to 1996, found that the relationship between inflation and growth is convex. At very low inflation rates (less than 2-3 per cent), inflation and growth are positively correlated but the relationship is negative when the level of inflation is high. Similarly, Nell (2000) also found that single-digit inflation may be beneficial for growth, while in the double-digit zone it appears to be harmful.

Motley (1998), using data from cross section of countries for the period 1960-1990, examined the effect of inflation on real growth in a Solow growth model and found that reduction in inflation would increase the growth rate of real GDP.

Non-linear effects of inflation on economic growth have also been tested (see for example Burdekin et al, 2000 and Gillman \& Kejak, 2000b). Inflation rate causes growth rate of the economy negatively but at lesser rates.

Mounting inflation has also been experienced by the economy of Brazil, therefore, this topic has been investigated by Faria and Carneiro (2001) for Brazil. They utilize a bi-variate time series model while employing the data from 1980 to 1995 . The VAR modeling technique discovered a short-run negative association which linking inflation and economic growth. However, they also found that there is no such association during the long run. Even such results are against the conception which representing the effects of inflation on economic growth in the long run but these could be taken as valuable addition in the literature so far.

Khan and Senhadji (2001) also contributed in the debate exploring the growth-inflation relationship. They also select the panel data set for analysis. They not only choose developing countries but also the industrialized countries for their sample of 140 while covering a time period from 1960 to 1998. They found out a verging level of inflation rate beyond which inflation affects economic growth negatively. They contended that verging point of inflation is different for developing and industrialized countries (e.g. for developing countries, it is 7-11 percent and for industrialized countries it is $1-3$ percent).

The growth-inflation inter-relationship has also been discovered by the Mallik and Chowdhury (2001) for the region of South Asia who selected four economies i.e. Bangladesh, India, Pakistan and Sri Lanka. They used secondary data sources of IMF and utilized time series analysis for the purpose of studying the relationship of economic growth and inflation dynamically in the framework of short run and long run time spaces. They found a positive and significant relationship in the study. In the inter-relationships of these two variables, the growth has been found to be comparatively more sensitive than inflation. On the basis of these results, it has been discovered first time in the economic literature that effects of inflation on growth could be cancelled out by the effects of growth on inflation. Hence, within the perspective of South Asian region where high inflation remains persistently and inevitably, such evidence may be served as a policy implication for the questioned inter-relationship.

Erricsson, Irons and Tryon (2001) found that regression analysis conducted to explore the relationship of inflation and growth has not been proved robust but signified a negative relationship. It is also concluded in the study that empirical and analytical misspecifications caused serious implications. The study does not support a long term relationship between economic growth and inflation because during the time series analysis these two variables were observed to be co-integrated. These co-integrating relationships showed that a positive correlation between growth and inflation which is a astounding result but authors justify the results in the perspective of price mark up model.

Caporin, and Maria (2002) selected 19 countries as a sample and empirically investigated the growth-inflation relationship in a regression which is based upon pooling strategy. Countries were grouped while keeping in view average level of inflation. They reached to the conclusion that regression coefficient of inflation varies with average inflation because of the fact that different countries experienced different level of inflation. Hence it could be concluded that average level of inflation may be a cause of improvement in explanatory power of the regression.

Gillman, Harris and Matyas (2002) focused on the countries belong to OECD and APEC region of the world. They also based on panel data for the analysis investigating growth-inflation association. They found that diminution of double digit inflation into single digit inflation significantly affects economic growth of OECD countries in a positive direction. However, these results have not fully been validated for APEC countries. As per conclusion effects of an anticipated diminution of inflation may be perceived when there is no growth deceleration at world 
level. In the absence of world level economic shocks the diminution in inflation may be able to enhance growth rate considerably.

Rousseau and Wachtel (2002) tried to find out the impact of inflation rate on growth of financial markets. They utilized a sample of 84 countries as a cross-section in a time series of time period from 1960 to 1965 . By using the technique relating to series of rolling panel they found that there exist a threshold of inflation rate within the range of 13 percent to 25 percent, which affects finance-growth association. The finance has been ceased to enhance economic growth as the inflation crossed the verging point of inflation.

Sweidan (2004) explored the economy of Jordan for the time period from 1970 to 2003 so as to investigate the nature of relationship cropping up between inflation and economic growth. The research results pointed out a significant positive relationship between the two, however, a breakout point of 2 percent have been recognized beyond which the relationship between the two have been observed to be negative.

A time series analysis has been conducted by Mubarik (2005) who tried to estimate a verging point of inflation in case of Pakistan economy. He selects a sample of 27 years from 1973 to 2000. He found threshold level of inflation at rate of 9 percent for the Pakistan economy while utilizing a threshold modeling. It could be easily concluded that a level of inflation below 9 percent may be considered as favorable for Pakistan. Robustness tests out of sensitivity analysis of the model also confirm the results of 9 percent for threshold analysis.

Hussain (2005) also investigated the threshold level of inflation for Pakistan economy while using time series data set from 1973 to 2005 and pointed out that a level of inflation within the range of 4 to 6 could be a taken as a threshold beyond which inflation would be a disincentive to economic growth.

A period of 1980 to 2005 has been used by Ahmed and Mortaza (2005) so as to analyze growth-inflation relationship while using the data of real GDP and consumer price index of Bangladesh economy. Refined time series econometric techniques have been employed by them for examining the relationship. They observed that a significant and negative relationship between CPI and GDP has been evident for a long time period. So far as a threshold level is concerned for inflation rate of the Bangladesh, they found it to be at level of 6 percent.

\section{Data Description}

Many studies available on the relationship between inflation and economic growth used cross-sectional data and panel data with the coverage of huge number of countries. For example, Barro (1995) and Khan and Senhadji (2001) used cross-sectional data and covered many countries in the analysis. Researchers prefer to use cross sectional data because single country usually lacks the diversity of inflation experiences necessary to explore if there is association between inflation and growth. However, any relationship between inflation and growth which has been found from cross section data loses significance when data from countries with $40 \%$ or more inflation are excluded from the analysis (Bruno and Easterly, 1995). Fischer (1993) also used panel data to take into consideration time dimension of inflation and growth. There are few studies which used time series data for analysis of individual countries. This study is based on secondary source of data on the annual observations of Pakistan Economy for the period 1960-2006. Data on Gross Domestic Product (GDP) (Note 8) and rate of Inflation has been obtained from the various issues of Pakistan Economic Survey.

\section{Methodological Issues and Model Specification}

The study employs the theory of co-integration and Error Correction Models (ECM) to observe the extent to which inflation is related to economic growth and vice versa. This procedure will help to study the long-run as well as short-run relationship between the two variables. Initially, some popular techniques i.e. the Augmented Dickey-Fuller (ADF, 1981) and the Phillips-Perron (PP, 1988), have been used to check for the presence of unit roots of the concerned time series variables. These tests have been performed in the levels as well as in the first difference. If all the series used in the study are integrated of the same order, the estimation of the following co-integration regression has been considered:

$$
\begin{aligned}
& \log (\mathrm{GDP})_{\mathrm{t}}=\alpha_{11}+\beta_{11} \operatorname{INFLR}_{\mathrm{t}}+\mu_{\mathrm{t}} \\
& \operatorname{INFLR}_{\mathrm{t}}=\alpha_{21}+\beta_{21} \log (\mathrm{GDP})_{\mathrm{t}}+\varepsilon_{\mathrm{t}}
\end{aligned}
$$

where $\log (G D P)_{t}$ is $\log$ of Gross Domestic Product, INFLR $R_{t}$ is rate of inflation at $t$ time and $\mu_{t}$ and $\varepsilon_{t}$ are random terms or residuals. To examine the extent to which GDP and INFLR are away from equilibrium, residuals $\mu_{t}$ and $\varepsilon_{t}$ are measured. If $\mu_{\mathrm{t}}$ and $\varepsilon_{\mathrm{t}}$ are integrated of zero order (it should be stationary at level), I(0), then it can be concluded that both $\mu_{\mathrm{t}}$ and $\varepsilon_{\mathrm{t}}$ are co-integrated and not expected to remain apart in the long-run. If co-integration exists, then obtained information on one variable can be used to predict other.

At first, Augmented Dickey-Fuller (ADF) test has been employed with as well as with out a time trend to verify the non-stationary property of each variable. Retain information that this test is the modification of the Dickey-Fuller 
(DF) test and lagged values of the dependent variables have been included in the estimation process. The test is based on the following model:

$$
\Delta \mathrm{Y}_{\mathrm{t}}=\alpha+\beta \mathrm{T}+(\rho-1) \mathrm{Y}_{\mathrm{t}-1}+\delta \Delta \mathrm{Y}_{\mathrm{t}-1}+\mathrm{e}_{1 \mathrm{t}}
$$

ADF test has advantage over the DF test that it takes care of possible serial correlation in the error terms by including the lagged difference of the dependent variable. Similarly, Phillips and Perron also take care of serial correlation in the error terms by using the nonparametric statistical method without addition of lagged difference terms. Moreover, the test developed by Phillips-Perron (PP) provides robust estimates over ADF test when there is presence of structural break as well as concerned time series has serial correlation. PP test is based on the following model:

$$
\Delta \mathrm{Y}_{\mathrm{t}}=\varphi+\beta(\mathrm{t}-\mathrm{T} / 2)+(\rho-1) \mathrm{Y}_{\mathrm{t}-1}+\chi \Delta \mathrm{Y}_{\mathrm{t}-1}+\mathrm{e}_{2 \mathrm{t}}
$$

MacKinnon (1991) provides the appropriate critical values of the t-statistic for the null hypothesis of non-stationary. In equation (2) and (3), $\Delta$ is the first difference operator and $e_{1 t}, e_{2 t}$ are the respective covariance stationary random error terms. Both tests have been carried out for the both variables by replacing $Y_{t}$ with GDP and Inflation in equation (2) and (3) for ADF test and PP test respectively. ADF and PP tests have also been employed for residuals of equation (1a) and (1b). When error terms (residuals) are found to be integrated of order zero (if these are stationary at level), I (0), and then it can be understood that these two series are co-integrated. A stable long-run relationship exists between inflation and economic growth, if the hypothesis of no integration is rejected.

There is an efficient procedure for testing the linear causation between the concerned variables i.e. Granger Causality. This test assumes that relevant information to the prediction of the respective variables, GDP and INFLR, is contained solely in the time series data on these variables. The test involves estimating the following pair of regression.

$$
\begin{aligned}
\log (G D P)_{t} & =\eta_{1} I_{N F L R} R_{t-i}+\eta_{2} \log (G D P)_{t-j} \\
\operatorname{INFLR~R~}_{t} & =\lambda_{1} \log (G D P)_{t-\mathrm{i}}+\lambda_{2} \operatorname{INFLR}_{\mathrm{t}-\mathrm{j}}
\end{aligned}
$$

When error terms $\left(\mu_{t}\right.$ and $\left.\varepsilon_{t}\right)$ are found to be co-integrated then there must exist an associated Error Correction Mechanism (Engle and Granger, 1987). ECM model may take the form:

$$
\begin{gathered}
\Delta \log (\mathrm{GDP})_{\mathrm{t}}=\eta_{0}+\eta_{1} \Delta \mathrm{INFLR}_{\mathrm{t}}+\eta_{2} \mu_{\mathrm{t}-1}+\mathrm{e}_{3 \mathrm{t}} \\
\Delta \operatorname{INFLR}_{\mathrm{t}}=\psi_{0}+\psi_{1} \Delta \log (\mathrm{GDP})_{\mathrm{t}}+\psi_{2} \varepsilon_{\mathrm{t}-1}+\mathrm{e}_{4 \mathrm{t}}
\end{gathered}
$$

where $\Delta$ stands for first difference operator, $\mathrm{e}_{3 \mathrm{t}}$ and $\mathrm{e}_{4 \mathrm{t}}$ are random error terms, and $\mu_{\mathrm{t}-1}$ and $\varepsilon_{\mathrm{t}-1}$ are:

$$
\begin{aligned}
\mu_{\mathrm{t}-1} & =\log (\mathrm{GDP})_{\mathrm{t}-1}-\alpha_{11}-\beta_{11} \operatorname{INFLR}_{\mathrm{t}-1}(\text { Rewrite from Equation 1a) } \\
\varepsilon_{\mathrm{t}-1} & =\beta_{11} \operatorname{INFLR}_{\mathrm{t}-1}-\alpha_{21}-\beta_{21} \log (\mathrm{GDP})_{\mathrm{t}-1}(\text { Rewrite from Equation 1b) }
\end{aligned}
$$

It means that the one-period lagged value of the error from the co-integrating regression. Equation (4) and (5) are the ECM equations which state that $\Delta$ Log (GDP) depends on $\Delta$ INFLR and vice versa for (5) and also on the equilibrium error term. If the latter of the equation (4) is non-zero, then the model is away from equilibrium. Suppose $\Delta$ INFLR is zero and $\mu_{t-1}$ is positive. It means that $\log (\mathrm{GDP})_{\mathrm{t}-1}$ is too high to be in equilibrium i.e. above the equilibrium value. Since, $\eta_{2}$ expected to be negative, the term $\eta_{2} \mu_{t-1}$ is negative and, therefore, $\log (\mathrm{GDP})_{\mathrm{t}}$ will be negative to restore the equilibrium. That is, if $\log (G D P)_{t}$ is above its equilibrium value, it will start to correct the equilibrium error, namely ECM. Similarly, if $\mu_{\mathrm{t}-1}$ is negative, $\log$ (GDP) is below its equilibrium value, $\eta_{2} \mu_{\mathrm{t}-1}$ is positive, which will cause Log (GDP) to be positive, and it will start to correct equilibrium error, namely, ECM. So, the estimated coefficients of error term indicate the short-run effect. In addition, three lags of both the explanatory variables and one lag of the error correction terms from the co-integrating regression have been included.

Khan and Senhadji (2001) estimated the threshold level of inflation for developing and also developed countries. Mubarik (2005) used the same model for Pakistan economy and Ahmed and Mortaza (2005) also used the same model for Bangladesh economy. Using the same model, consider the following equation to estimate the threshold level of inflation for Pakistan economy:

$$
\log (\mathrm{GDP})_{\mathrm{t}}=\chi_{0}+\chi_{1} \mathrm{INFLR}_{\mathrm{t}}+\chi_{2} \mathrm{D}\left(\mathrm{INFLR}_{\mathrm{t}}-\mathrm{K}\right)+\mathrm{C}_{\mathrm{t}}
$$

Where, $\mathrm{K}$ is threshold level of inflation at which structural break occurs, $\epsilon_{t}$ is random error term which represents measurement error in the explanatory variables (Note 9). The dummy variable is defined as follows:

$$
\begin{gathered}
\mathrm{D}=1 \text { if } \mathrm{INFLR}>\mathrm{K} \\
0 \text { if } \mathrm{INFLR} \leq \mathrm{K}
\end{gathered}
$$

When inflation rate is greater than assumed structural break level, $\chi_{2}$ measures the effect of inflation on GDP. At double inflation rate, $\left(\chi_{1}+\chi_{2}\right)$ represents the annual growth rate of GDP. $\mathrm{K}$ is chosen in an ascending order and optimal value of $\mathrm{K}$ is obtained by finding the value that maximizes the $\mathrm{R}^{2}$ from the respective regression. So, the 
threshold level is determined at which $\mathrm{R}^{2}$ maximizes. The process is repeated for several times at different values of $\mathrm{K}$. Inflation at the level, obtained from equation (6), has significant effect on GDP.

\section{Empirical Evidence}

Stationarity problem has been discussed before further analysis. Spurious regression phenomenon must be avoided in time series analysis. The results of the ADF test are reported in Table 1 and 2 (see appendix) with constant and with time trend and constant respectively. Log (GDP) and INFLR are not stationary time series at level even at $10 \%$ level of significance with constant and also with time trend and constant but these are stationary at $1^{\text {st }}$ difference at $1 \%$ level of significance. GDPG is also considered here and found stationary at level at $1 \%$ level of significance. But it is not considered for estimation and Log (GDP) is used as proxy variable in estimation. So, results of ADF test conclude that relevant time series are integrated of order one, I (1).

Results of the PP (Note 10) test are report in Table 3 and 4 (see appendix), with constant and with time trend and constant respectively. The results are consistent with of ADF test in spite of the fact that PP test provides robust estimates over ADF test when concerned time series has serial correlation and there is structural break.

\subsection{Model Estimation}

The outcome of the estimated model (1a) and (1b) is presented in Table (5) and (6). These results imply that there is positive relationship between inflation and economic growth for Pakistan. Inflation is positively related to economic growth but up to what level, we shall determine further. The coefficients are statistically significant and positive for both regressions (1a) and (1b). Furthermore, Table (5) illustrates that, over the period 1960 to 2006, Gross Domestic Product increased annually at the rate of 0.3 percent. Table (6) illustrates that, an increase in Gross Domestic Product of 1 percent, on average, leads to about 0.50 unit increase in inflation. These findings imply that both variables affect each other positively and have significant impact. It also implies that inflation is beneficial for economic growth in Pakistan in our sample period and economic growth is also increasing the rate of inflation in Pakistan.

\section{Insert Table 5, Table 6 Here}

Table (5) also illustrates that $26 \%$ variation in economic growth in positive direction is due to inflation in Pakistan. Our overall model is also good fit as indicated by F-Statistic. Table (5) implies that there is $43 \%$ variation in inflation is due to economic growth in Pakistan. This model is also good fit at $1 \%$ level of significance. Moreover, Autoregressive (AR) and Moving Average (MA) techniques have been used to tackle the problem of autocorrelation during estimation process. Our findings are different from Ahmed and Mortaza (2005). They found negative association between the same variables for Bangladesh and they concluded that inflation is harmful for economic growth in Bangladesh.

\subsection{Unit Root Test for Residuals}

Unit root tests for residuals of equations (1a) and (1b), i.e. $\mu_{t}$ and $\varepsilon_{t}$ have been performed in Table (7) and (8). Both tests (ADF and PP) imply that the residuals are integrated of order zero, I (0). This is interesting situation because both LGDP and INFLR are individually I (1), but the residuals terms of the model (1a) and (1b) is integrating of zero order, I (0) or stationary. Model (1a) and (1b) have stochastic trend but their linear combination will cancel out the stochastic trends in the two series and as a result it can be concluded that two variables are co-integrated and have long-run stable relationship.

\subsection{Granger Causality Tests}

Granger Causality has been employed to compute the linear causation between inflation and economic growth. Results are reported in table (9). It shows that the null hypothesis is rejected at 5-percent, which means that inflation is causing GDP growth. The causality between the two variables is uni-directed or in other words, there is no reverse causation from output growth to inflation. The second null hypothesis is not rejected at even 10 percent level of significance, which proves that there is no feed back from economic growth to inflation. This output of estimation also helps in the choice of dependent and independent variable for the threshold model specification. So, according to Granger Causality analysis, inflation is causing GDP growth at lag three (lag = 3) for the period of 1960-2006.

Insert Table 9 Here

\subsection{Error Correction Mechanism}

Sargan and Bhargava (1983 used Error Correction Mechanism (ECM) for first time (Note 11) and later it was popularized by Engle and Granger corrects for equilibrium. An important theorem which is known as the Granger representation theorem, describes that if two variables are co-integrated, then the relationship between the two can be expressed as ECM. The ECM has numerous advantages: first, it incorporates both the long-run and short-run effects assuming that the concerned variables are co-integrated. Secondly, assuming co-integration; all the terms in the model are stationary so that standard regression techniques are valid (Ahmed and Mortaza, 2005). 


\section{Insert Table 10 Here}

Tables (10) and (11) present estimated coefficients of the error correction term (short-run effects) and the lagged values of the series (long-run effects). These models have been estimated up to three lags (Note 12) of the explanatory variables and one lag of the error terms. The upshot shows the presence of a significant relationship between inflation and economic growth for Pakistan in the short-run. The estimated coefficient of the error correction term of model (4) is significant at $1 \%$ level of significance and has negative sign. This implies that INFLR is too away to be in equilibrium, that is, INFLR is away from its equilibrium value. For instance, the error correction term -0.49 implies that 49 percent of the adjustments towards the short-run equilibrium relation for Pakistan occur within a year through changes in growth rates. Lagged values of the explanatory variable (INFLR) indicate the long-run effects. In long-run, there are mixed results, indicating that inflation affect economic growth negatively at lag two and positively at lag one and three. The estimated coefficient of the error term of the model (5) is also significant at $1 \%$ level of significance and has negative sign. This result implies that 58 percent (error correction term -0.58) of the deviation of the INFLR from its long-run equilibrium level is corrected each year. So, the estimated results in the ECM imply that inflation affects economic growth negatively and economic growth also has same effect on inflation in the short-run in Pakistan.

Insert Table 11 Here

\subsection{Threshold Model Estimation}

The estimations of the equation (6), by using OLS methodology, are reported in table (12) which gives the exact value of the threshold inflation level. The process has been repeated several times. The estimated R-square is taken into account for the threshold level of inflation considering the values of $\mathrm{K}$ from 1 to 13 . However, considering the value of R-square, the estimated results have been reported in the table (12) for $\mathrm{K}$ values ranging from $4 \%$ to $12 \%$. So, according to this approach, the threshold level is one that maximizes the value of R-square. It can be observed from the estimated results that at $\mathrm{K}=4$, there is insignificant relationship between the dummy of threshold level of inflation and economic growth. As $\mathrm{K}$ increases and at $\mathrm{K}=6$, there is significant relationship between the dummy of threshold level of inflation and economic growth. At all values of $\mathrm{K}$, positive relationship has been found between inflation and economic growth. At $K=4$, the value of $R^{2}$ is 0.27 . As $K$ starts to increase, $R^{2}$ is also increasing and has highest value at $K=9$ i.e. 0.41 . After that $R^{2}$ starts to decrease and at $K=12$, the value of $R^{2}$ is 0.35 . Finally, 9 percent level is a threshold level, which is obtained by finding that value of $\mathrm{K}$ that maximizes the $\mathrm{R}^{2}$.

After a detailed empirical examination, it can be concluded that there is positive association between inflation and economic growth in the context of Pakistan and vice versa. As for as, the concern of causality between these two variables, the causality is uni-directed as indicated by the Granger Causality tests. We found short-run and long-run relationship between inflation and economic growth in Pakistan. Furthermore, estimations for the threshold level of inflation imply that up to $9 \%$, inflation rate is beneficial for economic growth.

\section{Conclusion and Policy Implications}

This study has been an attempt to empirically explore the effects of inflation on economic growth of Pakistan and vice versa. A judgment of the empirical evidence has been obtained through the co-integration and error correction models to examine the long-run and short-run dynamics of the inflation-growth relationship. In addition, the study also discovers an interesting policy issue of what is the threshold level of inflation for the economy. The empirical evidence suggests that there is positive relation between inflation and economic growth in Pakistan. Malik and Chowdhury (2001) also establish a positive connection between inflation and economic growth. This result is different from the predictions of Mubarik (2005). He finds negative association between inflation and economic growth. But our findings imply that both variables affect each other positively and have significant impact. In fact, our results can be justified as the Tobin portfolio-shift effect i.e. high inflation rate leads people to invest more in physical capital and cut their real balance holdings. The Granger test employed to check the linear causation implies that inflation affect growth at lag three while there is no reverse causation from out put growth to inflation. Our empirical findings also demonstrate that there is significant relationship between the two variables in the long-run.

Furthermore, the estimated threshold model suggests that 9 percent threshold level (i.e. structural break point) of inflation above which inflation starts to lower the economic growth in Pakistan. This result is consistent with Mubarik (2005) who also recommended 9 percent threshold level of inflation for economic growth. The results of this study also suggest that below the estimated level of 9 percent is conducive for economic growth in Pakistan. Khan and Senhadji (2001) find little bit different results from our study i.e. 11-12 percent threshold level of inflation for developing countries in their cross-country study. Sarel (1995) also recommended that below 8 percent inflation may have a slightly positive effect on growth. So, to sum up the results of this study, it can be concluded that inflation-growth relationship is positive and above 9 percent level of inflation, it slows the economic growth. 
These findings have some policy implications for the policymakers and development partners. This study is inconsistent with policy suggestions by international agencies. Efforts to minimize inflation to a very low level (or zero) are likely to adversely affect economic growth. However, attempts to achieve faster economic growth may overheat the economy to the extent that the inflation rate becomes unstable. The economy is on a knife-edge (Malik and Chowdhury, 2001). The real challenge for the government of Pakistan is to achieve a growth rate which is consistent with a stable inflation rate, rather than beat inflation first to take it to a path of faster growth. Pakistan must need inflation for growth, but too fast a growth rate may also accelerate the inflation rate. Policymakers throughout the world during the last decade or so have recognized that lowering inflation is conducive to improved growth performance. So, the goal that the government of Pakistan has to achieve is of keeping inflation to single digit, or close to single digit.

\section{References}

Afridi Usman and Asghar Qadir (1982). Dual Sector Inflation in Pakistan, Research Report Series No. 136, PIDE, Islamabad.

Ahmed, Shamim and M. G. Mortaza (2005). Inflation and Economic Growth in Bangladesh: 1981-2005, Working Paper Series: WP 0604, Policy Analysis Unit (PAU). Research Department, Bangladesh Bank.

Akhtaruzzaman, Md. (2005). Inflation in the Open Economy: An Application of the Error Correction Approach to the Recent Experience in Bangladesh, Working Paper Series, WP 0602, Policy Analysis Unit (PAU)., Research Department, Bangladesh Bank.

Andres, Javier and Ignacio Hernando (1997). Does Inflation Harm Economic Growth? Evidence for the OECD, Working Paper 6062, National Bureau of Economic Research.

Barro, Robert J. (1995). Inflation and Economic Growth, Working Paper 5326, National Bureau of Economic Research.

(1996). Inflation and Growth, Federal Reserve Bank of St. Louis Review, vol.78, pp. 153-169.

Bilquees, Faiz (1987). Inflation in Pakistan 1959-60, 1981-82: A Review, Research Reports Series No. 153, PIDE, Islamabad.

Black, J. (1959). Inflation and Long-Run Growth, Economica, New Series, Vol. 26, No. 102, pp. 145-153.

http://dx.doi.org/10.2307/2550393

Boyd, John and Bruce Champ (2006). Inflation, Banking and Economic Growth, Research Department, Federal Reserve Bank of Cleveland.

Bruno, Michel and William Easterly (1995). Inflation Crises and Long-Run Growth, World Bank Policy Research, Working Paper No. 1517.

(1996). Inflation and Growth: In Search of Stable Relationship, Federal Reserve Bank of St. Louis Review, Vol. 78, No. 3.

Burdekin, Richard C. K. et al (2000). When Does Inflation Hurt Economic Growth? Different Nonlinearities for Different Economies, Working Papers in Economics, Claremont Colleges.

Caporin, M. and C. Di Maria (2002). Inflation and Growth: some panel data evidence, Working Paper n.02.09, GRETA.

Davis, George K. and Bryce E. Kanago (1998). Inflation, Inflation Uncertainty, Political Stability, and Economic Growth, Department of Economics, Miami University, Oxford.

De Gregorio, Jose. (1991). The Effects of Inflation on Growth: Lessons from Latin America, IMF Working Paper, WP/91/95, Research Department, International Monetary Fund.

The World Bank.

(1996). Inflation, Growth and Central Banks: Theory and Evidence, Policy Research Working Paper 1575,

(2004). Rapid Growth of Monetary Aggregates and Inflation: The International Evidence, Working Papers, No. 256, Central Bank of Chile.

Dornbusch, Rudiger and Jacob A. Frenkel (1973). Inflation and Growth: Alternative Approaches, Journal of Money, Credit and Banking, Vol. 5, No. 1, Part I. pp. 141-156.

Edwards, Sebastian and I. Igal Magendzo (2001). Dollarization, Inflation and Growth, National Bureau of Economic Research.

Engle, R. F. and C. W. J. Granger (1987). Co-integration and Error Correction: Representation, Estimation and Testing, Econometrica, Vol. 55, pp. 1-87. http://dx.doi.org/10.2307/1913236

Ercel, Gazi (1999). The Relationship between Inflation and Growth, Central Bank of the Republic of Turkey. 
Erricsson, N. R., J. S. Irons, and R. W. Tryon (2001). Output and Inflation in the Long Run, Journal of Applied Econometrics, Vol. 16, No. 3, pp. 241-253.

http://dx.doi.org/10.1002/jae.614

Faria, J. R. and F. G. Carneiro (2001). Does Inflation Affect Growth in the Long and Short run?, Journal of Applied Economic, Vol. IV, No. 1. pp. 89-105.

Fifty Years of Pakistan in Statistics, Vol. I to IV. Federal Bureau of Statistics, Islamabad.

Fischer, Stanley (1983). Inflation and Growth, Working Paper No. 1235, National Bureau of Economic Research. $\overline{485-512 .}$

(1993). The Role of Macroeconomic Factors in Growth, Journal of Monetary Economics, Vol. 32, pp.

Frenkel, Michael and Gil Mehrez (1998). Inflation and Endogenous Technological Growth, Department of Economics, WHU Koblenz, Otto Beisheim Graduate School of Management, Burgplatz 2, 56179 Vallendar, Germany.

Ghosh, Atish and Steven Phillips (1998). Inflation, Disinflation and Growth, IMF Working Paper, WP/98/68.

. (1998). Warning: Inflation May Be Harmful to Your Growth, IMF Staff Papers, International Monetary Fund, Vol. 45, No. 4, pp.672-710.

Gillman, Max, and Michal Kejak, (2000b)., A Non-linearity in the Inflation-Growth Effect, Central European University Department of Economics Working Paper 14/2000; revised.

Gillman, M., M. Harris and Laszlo Matyas (2002). Inflation and Growth: Some Theory and Evidence, Berlin: 10th International Conference on Panel Data.

Gokal, Vikesh and Subrina Hanif (2004). Relationship between Inflation and Economic Growth, Working Paper 2004/04, Economics Department, Federal Reserve Bank of Fiji, Suva, Fiji. Government of Pakistan, Pakistan Economic Survey, Various issues.

Hand Book of Statistics on Pakistan Economy, 2005, State Bank of Pakistan.

Hussain, Manzoor (2005). Inflation and Growth: Estimation of Threshold Point for Pakistan, Economic Policy Department, State Bank of Pakistan.

Khalid, Ahmed M. (2005). Economic Growth, Inflation and Monetary Policy in Pakistan: Some Empirical Estimates, paper presented at 21st Annual General Meeting and Conference of PSDE, 19-21 December, 2005.

Khan, Mohsin S. and Abdelhak S. Senhadji (2001). Threshold Effects in the Relationship Between Inflation and Growth, IMF Staff Papers, Vol. 48, No. 1

Khan Ashfaque H. and M. A. Qasim (1996). Inflation in Pakistan Revisited, The Pakistan Development Review, Vol. 35, No. 4, Part II, pp. 747-759.

Li, Min (2005). Inflation and Economic Growth: Threshold Effects and Transmission Mechanisms, Department of Economics, University of Alberta, Alberta, Canada.

Malla, Sunil. (1997). Inflation and Economic Growth: Evidence from a Growth Equation, Department of Economics, University of Hawaiâ TMI at Monoa, Honoulu, USA.

Mallik, Girijasankar and Anis Chowdhury (2001). Inflation and Economic Growth: Evidence from four South Asian Countries, Asia-Pacific Development Journal, Vol. 8, No. 1. pp. 123-135.

Mamalakis, Markos (1963). Inflation and Growth: An Asset Preference Analysis, with a case study of Chilean Inflation, The Journal of Finance, Vol. 18, No.3, pp.553-554. http://dx.doi.org/10.2307/2977561

Mankiw, Gregory N. (2000). Macroeconomics, 4th Edition, New York, Worth.

Motley, Brian (1993). Inflation and Growth, Federal Reserve Bank of San Francisco Weekly Letter, Number 93-44.

Motley, Brian (1998). Growth and Inflation: A Cross-Country Study, Federal Reserve Bank of San Francisco Economic Review, No. 1.

Mubarik, Y. A. (2005). Inflation and Growth: An Estimate of the Threshold Level of Inflation in Pakistan, State Bank of Pakistan, Research Bulletin, Vol. 1-2, pp. 35-44.

Naqvi, S. N. H. and Ashfaque H. Khan (1989). Inflation and Growth: An Analysis of Recent Trends in Pakistan, Pakistan Institute of Development Economics, Islamabad.

Nell, Kevin S. (2000). Is Low Inflation a Precondition for Faster Growth? The Case of South Africa, Working papers in Economics, Department of Economics, Keynes College, University of Kent. Pakistan Economic Survey, Various issues. 
Paldam, Martin (1973). An Empirical Analysis of the Relationship between Inflation and Economic Growth in 12 Countries, 1950 to 1969, The Swedish Journal of Economics, Vol. 75, No. 4, pp. 420-427. http://dx.doi.org/10.2307/3439152

Palokangas, Tapio (1997). Inflation and Growth in an Open Economy, Economica, New Series, Vol. 64, No. 255, pp. 509-518. http://dx.doi.org/10.1111/1468-0335.00094

Phillips, A. W. (1962). Employment, Inflation and Growth, Economica, New Series, Vol. 29, No. 113, pp. 1-16. http://dx.doi.org/10.1111/j.1468-0335.1962.tb00001.x

Phillips, P. C. B. and P. Perron (1998). Testing for a Unit Root in Time Series Regression, Biometrika, Vol. 32, pp. 301-318.

Rousseau, Peter L. and Paul Wachtel (2002). Inflation Thresholds and the finance-growth nexus, Journal of International Money and Finance, Vol. 21, pp. 777-793. http://dx.doi.org/10.1016/S0261-5606(02)00022-0

Sarel, M. (1995). Nonlinear Effects of Inflation on Economic Growth, IMF Working Paper WP/95/56, Washington.

Sweidan, O. D. (2004). Does Inflation Harm Economic Growth in Jordan? An Econometric Analysis for the Period 1970-2000, International Journal of Applied Econometrics and Quantitative Studies, Vol. 1-2, pp. 41-66.

\section{Notes}

Note 1. There are two popular price indices. 1- Consumer Price Index (CPI) measures the retail prices of a fixed "market basket" of several goods and services purchased by households. 2- Producer Price Index (PPI) measures the wholesale prices of thousand items.

Note 2. Demand-pull inflation is a monetary phenomenon, related with money supply.

Note 3. See Fischer (1983 and 1993), Bruno and Easterly (1996), Malla (1997), Faria and Carneiro (2001), Mubarik (2005) etc.

Note 4.The regression in which the dependent variable is related to a single explanatory variable.

Note 5.The regression in which the dependent variable is related to more than one variable.

Note 6.Investment, real gross capital formation, money supply and population growth etc. are considered conditioning variables in growth analysis

Note 7. For details of the model, see Naqvi and Khan (1989).

Note 8. GDP has been taken at current factor cost.

Note 9. Control or conditional variables have not been used in this study. For reasons, see section 1 of this study.

Note 10. Phillips-Perron test has been performed at truncation lag three suggested by Newey-West.

Note 11. Sargan, J. D. and A. S. Bhargava (1983) "Testing Residuals from Least-Squares Regression for being generated by the Gaussian Random Walk”, Econometrica, Vol. 51, pp. 153-174.

Note 12. Lag length is determined by the Granger Causality test.

Table 1. Augmented Dickey-Fuller Test with Intercept

\begin{tabular}{|c|c|c|c|}
\hline Variables & Level & $1^{\text {st }}$ Difference & Conclusion \\
\hline Log (GDP) & 0.88 & -4.59 & $\mathrm{I}(1)$ \\
INFLR & -3.09 & -6.42 & $\mathrm{I}(1)$ \\
GDPG & -5.49 & -- & $\mathrm{I}(0)$ \\
\hline
\end{tabular}

Source: Author's calculations based on E-views 5.0 software.

Table 2. Augmented Dickey-Fuller Test with Trend and Intercept

\begin{tabular}{|c|c|c|c|}
\hline Variables & Level & $1^{\text {st }}$ Difference & Conclusion \\
\hline Log (GDP) & -2.9 & -4.54 & $\mathrm{I}(1)$ \\
INFLR & -3.05 & -6.35 & $\mathrm{I}(1)$ \\
GDPG & -5.73 & -- & $\mathrm{I}(0)$ \\
\hline
\end{tabular}

Source: Author's calculations based on E-views 5.0 software.

Table 3. Phillips-Perron Test with Intercept

\begin{tabular}{|c|c|c|c|}
\hline Variables & Level & $1^{\text {st }}$ Difference & Conclusion \\
\hline Log (GDP) & 0.71 & -4.49 & $\mathrm{I}(1)$ \\
INFLR & -3.09 & -6.48 & $\mathrm{I}(1)$ \\
GDPG & -5.44 & -- & $\mathrm{I}(0)$ \\
\hline
\end{tabular}

Source: Author's calculations based on E-views 5.0 software. 
Table 4. Phillips-Perron Test with Trend and Intercept

\begin{tabular}{|c|c|c|c|}
\hline Variables & Level & $1^{\text {st }}$ Difference & Conclusion \\
\hline Log (GDP) & -3.04 & -4.44 & $\mathrm{I}(1)$ \\
INFLR & -3.05 & -6.4 & $\mathrm{I}(1)$ \\
GDPG & -5.66 & -- & $\mathrm{I}(0)$ \\
\hline
\end{tabular}

Source: Author's calculations based on E-views 5.0 software.

Table 5. Augmented Dickey-Fuller Test for Residuals of (1a) and (1b)

\begin{tabular}{|c|c|c|c|}
\hline Error term & $\begin{array}{c}\text { Level } \\
\text { (with intercept) }\end{array}$ & $\begin{array}{c}\text { Level } \\
\text { (with trend and intercept) }\end{array}$ & Conclusion \\
\hline$\mu_{\mathrm{t}}$ & -6.71 & -6.66 & $\mathrm{I}(0)$ \\
$\varepsilon_{\mathrm{t}}$ & -6.36 & -6.34 & $\mathrm{I}(0)$ \\
\hline
\end{tabular}

Source: Author's calculations based on E-views 5.0 software.

Table 6. Phillips-Perron Test for Residuals of (1a) and (1b)

\begin{tabular}{|c|c|c|c|}
\hline Error term & $\begin{array}{c}\text { Level } \\
\text { (with intercept) }\end{array}$ & $\begin{array}{c}\text { Level } \\
\text { (with trend and intercept) }\end{array}$ & Conclusion \\
\hline$\mu_{\mathrm{t}}$ & -6.70 & -6.65 & $\mathrm{I}(0)$ \\
$\varepsilon_{\mathrm{t}}$ & -6.35 & -6.33 & $\mathrm{I}(0)$ \\
\hline
\end{tabular}

Source: Author's calculations based on E-views 5.0 software.

Table 7. Estimation of the Log (GDP) Model (1a)

\begin{tabular}{|c|c|c|c|c|c|}
\hline \multicolumn{6}{|c|}{$\begin{array}{l}\text { Dependent Variable: } \Delta \log (\mathrm{GDP}) \\
\text { Method: OLS } \\
\text { Sample: } 1960-2006\end{array}$} \\
\hline Variables & Coefficients & & Standard Error & t-Statistic & \\
\hline $\begin{array}{l}\text { Constant } \\
\triangle \text { INFLR } \\
\text { MA(1) }\end{array}$ & $\begin{array}{l}0.132 \\
0.003 \\
0.398\end{array}$ & & $\begin{array}{l}0.009 \\
0.001 \\
0.142\end{array}$ & $\begin{array}{l}13.954 \\
2.216^{* *} \\
2.807\end{array}$ & \\
\hline \multirow{2}{*}{\multicolumn{3}{|c|}{$\begin{array}{l}\text { R-squared } \\
0.268\end{array}$}} & \multirow{2}{*}{\multicolumn{2}{|c|}{ Mean dependent variable }} & 0.132 \\
\hline & & & & & 0.051 \\
\hline \multicolumn{2}{|l|}{ Adjusted R-squared } & 0.233 & \multicolumn{2}{|l|}{ Akaike info criterion (AIC) } & -3.302 \\
\hline \multicolumn{2}{|l|}{ S.E. of Regression } & 0.045 & \multicolumn{2}{|l|}{ Schwarz criterion } & -3.180 \\
\hline \multicolumn{2}{|l|}{ Sum squared residual } & 0.083 & \multicolumn{2}{|l|}{ F-statistic } & \\
\hline \multicolumn{2}{|l|}{ Log-likelihood } & 75.639 & \multicolumn{3}{|l|}{$7.521^{*}$} \\
\hline \multicolumn{2}{|l|}{ Durban-Watson statistic } & 1.964 & Probability (F-statistic) & & 0.002 \\
\hline
\end{tabular}

Source: Author's calculations based on E-views 5.0 software.

Note: $* * *, * *$ indicates level of significance at $1 \%, 5 \%$ and $10 \%$ respectively.

Table 8. Estimation of the INFLR Model (1b)

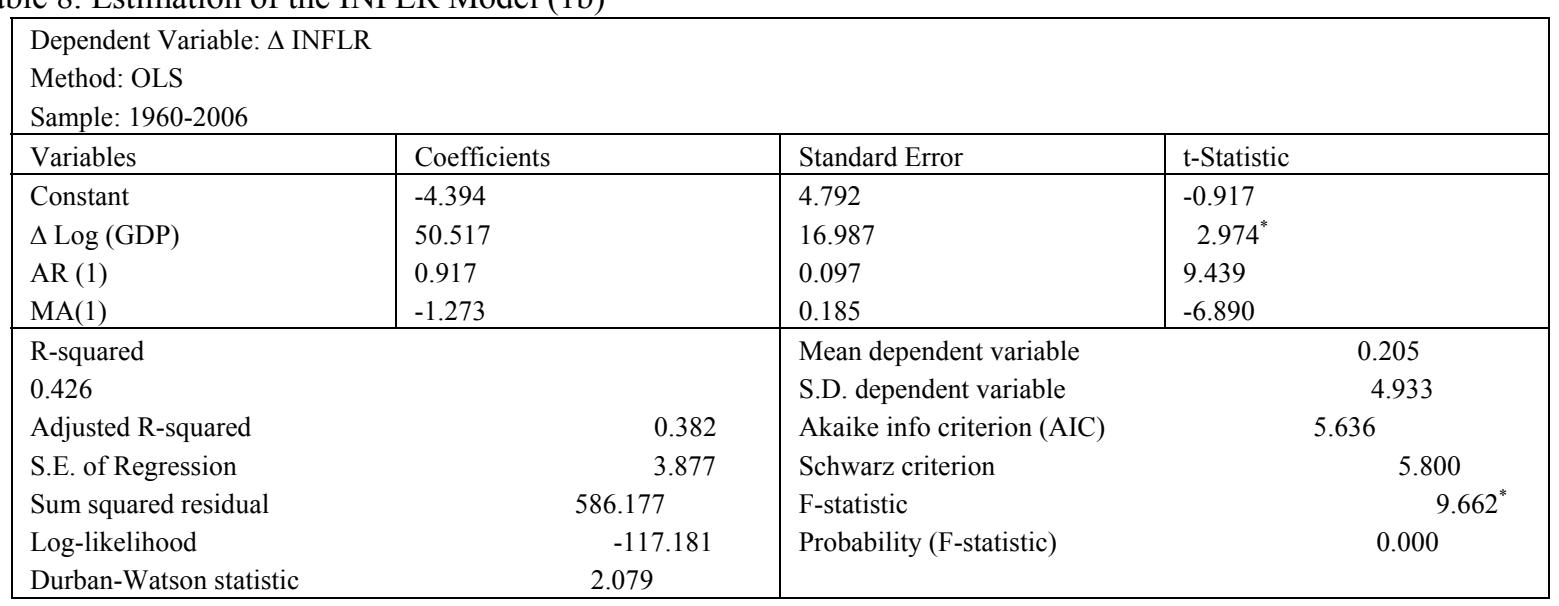

Source: Author's calculations based on E-views 5.0 software.

Note: $* * *, * *$ indicates level of significance at $1 \%, 5 \%$ and $10 \%$ respectively. 
Table 9. Pair wise Granger Causality Tests

\begin{tabular}{|c|c|c|c|c|}
\hline \multicolumn{5}{|l|}{ Sample: 1960-2006 } \\
\hline \multicolumn{5}{|l|}{ Lags: 3} \\
\hline Null Hypothesis & & Observations & F-Statistics & Probability \\
\hline INFLR does not Granger cause LGDP & 42 & & 3.45584 & 0.02667 \\
\hline LGDP does not Granger cause INFLR & 42 & & 1.57539 & 0.21273 \\
\hline
\end{tabular}

Source: Author's calculations based on E-views 5.0 software.

Table 10. Estimation of the Model (4) (Error Correction Model)

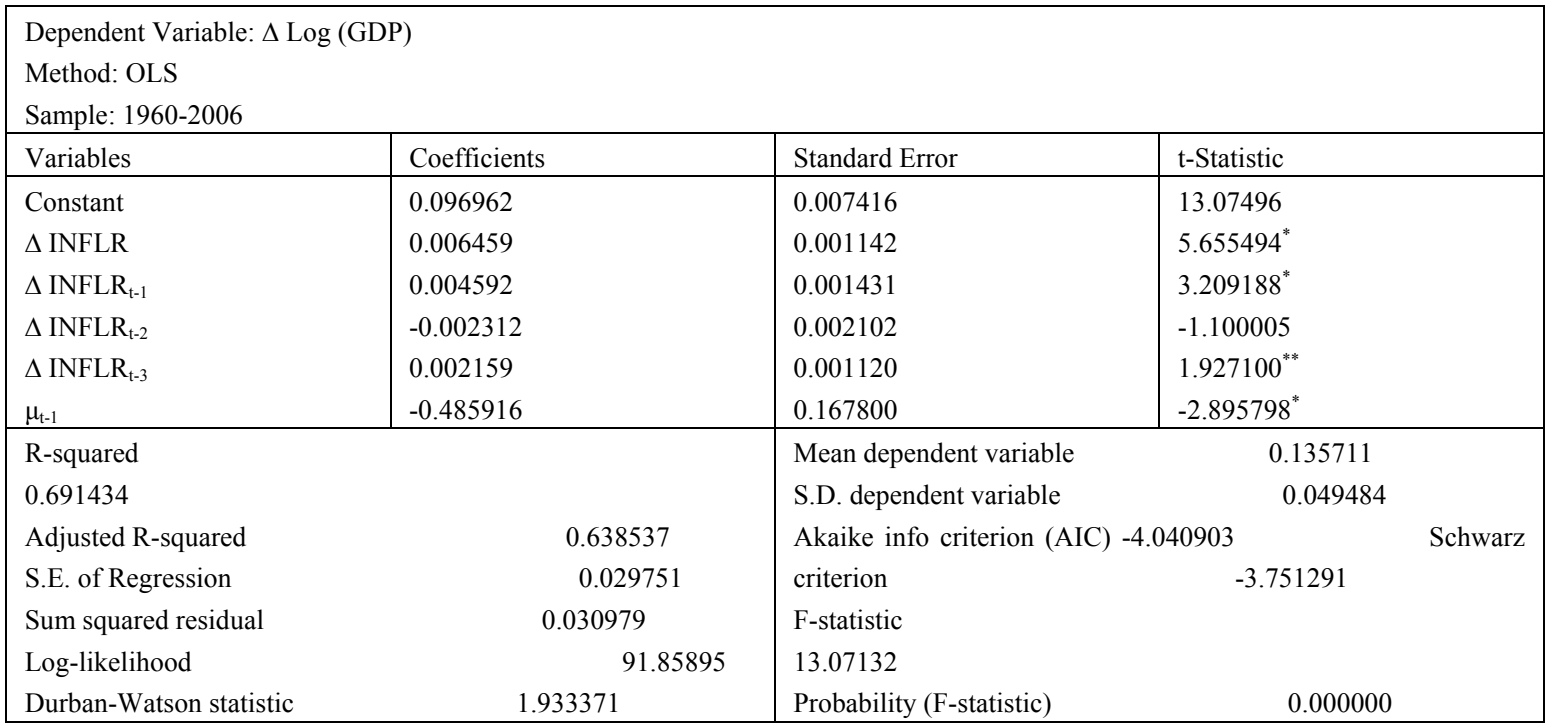

Source: Author's calculations based on E-views 5.0 software.

Note: ${ }^{* *}, * * *$ indicates level of significance at $1 \%, 5 \%$ and $10 \%$ respectively.Table 11 . Estimation of the Model (5)

(Error Correction Model)

Dependent Variable: $\triangle$ INFLR

Method: OLS

Sample: $1960-2006$

\begin{tabular}{|c|c|c|c|}
\hline Variables & Coefficients & Standard Error & t-Statistic \\
\hline Constant & 6.288985 & 2.777715 & 2.264086 \\
\hline$\Delta \log (\mathrm{GDP})$ & 50.65782 & 14.45103 & $3.505481^{*}$ \\
\hline$\Delta \log (\mathrm{GDP})_{\mathrm{t}-1}$ & -6.768823 & 12.07026 & -0.560785 \\
\hline$\Delta \log (\mathrm{GDP})_{\mathrm{t}-2}$ & -68.70779 & 16.19191 & $-4.243341^{*}$ \\
\hline$\Delta \log (\mathrm{GDP})_{\mathrm{t}-3}$ & 75.30213 & 11.65696 & $6.459840 *$ \\
\hline$\varepsilon_{\mathrm{t}-1}$ & -0.578995 & 0.135758 & -4.264894 \\
\hline R-squared & & Mean dependent variable & 0.235714 \\
\hline 0.586447 & & S.D. dependent variable & 4.988075 \\
\hline Adjusted R-squared & 0.515552 & Akaike info criterion (AIC) & 5.478243 \\
\hline S.E. of Regression & 3.471813 & Schwarz criterion & 5.767855 \\
\hline Sum squared residual & 421.8721 & F-statistic & \\
\hline Log-likelihood & -108.0431 & 8.272077 & \\
\hline Durban-Watson statistic & 2.335634 & Probability (F-statistic) & 0.000013 \\
\hline
\end{tabular}

Source: Author's calculations based on E-views 5.0 software.

Note: *,**,*** indicates level of significance at $1 \%, 5 \%$ and $10 \%$ respectively. 
Table 12. Economic Growth Model at $\mathrm{K}=4$ to 12

(Dependent Variable: Log (GDP))

\begin{tabular}{|c|c|c|c|c|c|c|}
\hline $\mathrm{K}$ & Variable & Coefficient & $\begin{array}{c}\text { Standard } \\
\text { Error }\end{array}$ & t-statistic & Probability & R-squared \\
\hline 4 Percent & $\begin{array}{c}\text { Constant } \\
\text { INFLR } \\
\text { D(INFLR-K) }\end{array}$ & $\begin{array}{l}0.1311 \\
0.0035 \\
0.0043\end{array}$ & $\begin{array}{l}0.0191 \\
0.0014 \\
0.0193\end{array}$ & $\begin{array}{c}6.8693 \\
2.4616^{*} \\
0.2215\end{array}$ & $\begin{array}{l}0.0000 \\
0.0184 \\
0.8258\end{array}$ & 0.27 \\
\hline $\begin{array}{c}5 \\
\text { Percent }\end{array}$ & $\begin{array}{c}\text { Constant } \\
\text { INFLR } \\
\text { D(INFLR-K) }\end{array}$ & $\begin{array}{l}0.1167 \\
0.0032 \\
0.0274\end{array}$ & $\begin{array}{l}0.0130 \\
0.0014 \\
0.0160\end{array}$ & $\begin{array}{c}8.9555 \\
2.3270^{* *} \\
1.7133\end{array}$ & $\begin{array}{l}0.0000 \\
0.0253 \\
0.0946\end{array}$ & 0.30 \\
\hline $\begin{array}{c}6 \\
\text { Percent }\end{array}$ & $\begin{array}{c}\text { Constant } \\
\text { INFLR } \\
\text { D(INFLR-K) }\end{array}$ & $\begin{array}{l}0.1108 \\
0.0027 \\
0.0432 \\
\end{array}$ & $\begin{array}{l}0.0107 \\
0.0013 \\
0.0145 \\
\end{array}$ & $\begin{array}{c}10.3783 \\
2.0062^{* *} \\
2.9851^{*}\end{array}$ & $\begin{array}{l}0.0000 \\
0.0518 \\
0.0049 \\
\end{array}$ & 0.38 \\
\hline $\begin{array}{c}7 \\
\text { Percent }\end{array}$ & $\begin{array}{c}\text { Constant } \\
\text { INFLR } \\
\text { D(INFLR-K) }\end{array}$ & $\begin{array}{l}0.1125 \\
0.0029 \\
0.0415\end{array}$ & $\begin{array}{l}0.0104 \\
0.0013 \\
0.0145\end{array}$ & $\begin{array}{c}10.8669 \\
2.1437^{* *} \\
2.8653^{*}\end{array}$ & $\begin{array}{l}0.0000 \\
0.0384 \\
0.0067\end{array}$ & 0.37 \\
\hline $\begin{array}{c}8 \\
\text { Percent }\end{array}$ & $\begin{array}{c}\text { Constant } \\
\text { INFLR } \\
\text { D(INFLR-K) }\end{array}$ & $\begin{array}{l}0.1151 \\
0.0025 \\
0.0448\end{array}$ & $\begin{array}{l}0.0093 \\
0.0013 \\
0.0145\end{array}$ & $\begin{array}{c}12.3684 \\
1.8963^{* * *} \\
3.0966^{*}\end{array}$ & $\begin{array}{l}0.0000 \\
0.0653 \\
0.0036\end{array}$ & 0.38 \\
\hline $\begin{array}{c}9 \\
\text { Percent }\end{array}$ & $\begin{array}{c}\text { Constant } \\
\text { INFLR } \\
\text { D(INFLR-K) }\end{array}$ & $\begin{array}{l}0.1139 \\
0.0028 \\
0.0501 \\
\end{array}$ & $\begin{array}{l}0.0085 \\
0.0013 \\
0.0136 \\
\end{array}$ & $\begin{array}{c}13.4655 \\
2.1870^{* *} \\
3.6867^{*}\end{array}$ & $\begin{array}{l}0.0000 \\
0.0348 \\
0.0007 \\
\end{array}$ & 0.41 \\
\hline $\begin{array}{c}10 \\
\text { Percent }\end{array}$ & $\begin{array}{c}\text { Constant } \\
\text { INFLR } \\
\text { D(INFLR-K) }\end{array}$ & $\begin{array}{l}0.1193 \\
0.0031 \\
0.0447 \\
\end{array}$ & $\begin{array}{l}0.0087 \\
0.0013 \\
0.0151 \\
\end{array}$ & $\begin{array}{l}13.6648 \\
2.3817^{* *} \\
2.9660^{* *}\end{array}$ & $\begin{array}{l}0.0000 \\
0.0222 \\
0.0051 \\
\end{array}$ & 0.38 \\
\hline $\begin{array}{c}11 \\
\text { Percent }\end{array}$ & $\begin{array}{c}\text { Constant } \\
\text { INFLR } \\
\text { D(INFLR-K) }\end{array}$ & $\begin{array}{l}0.1222 \\
0.0033 \\
0.0493\end{array}$ & $\begin{array}{l}0.0079 \\
0.0013 \\
0.0165\end{array}$ & $\begin{array}{l}15.5387 \\
2.4927^{*} \\
2.9838^{*}\end{array}$ & $\begin{array}{l}0.0000 \\
0.0170 \\
0.0049\end{array}$ & 0.36 \\
\hline $\begin{array}{c}12 \\
\text { Percent }\end{array}$ & $\begin{array}{c}\text { Constant } \\
\text { INFLR } \\
\text { D(INFLR-K) }\end{array}$ & $\begin{array}{l}0.1273 \\
0.0023 \\
0.0561 \\
\end{array}$ & $\begin{array}{l}0.0079 \\
0.0014 \\
0.0232\end{array}$ & $\begin{array}{c}16.0925 \\
1.6239 \\
2.5217^{*}\end{array}$ & $\begin{array}{l}0.0000 \\
0.1124 \\
0.0159\end{array}$ & 0.35 \\
\hline
\end{tabular}

Source: Author's calculations based on E-views 5.0 software.

Note: $*, * * * *$ indicates level of significance at $1 \%, 5 \%$ and $10 \%$ respectively.

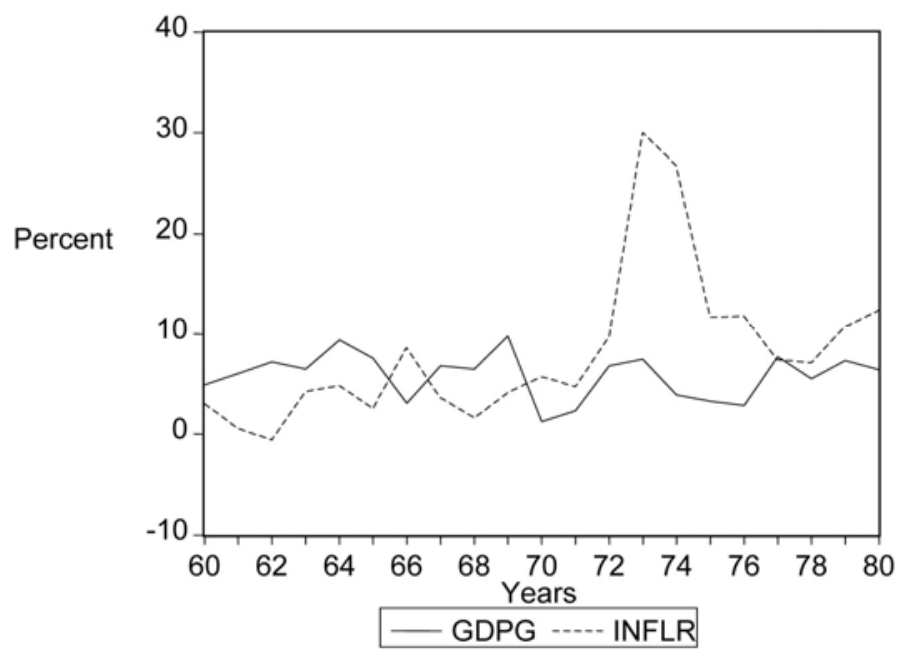

0)

Source: Pakistan Economic Survey (various issues) 


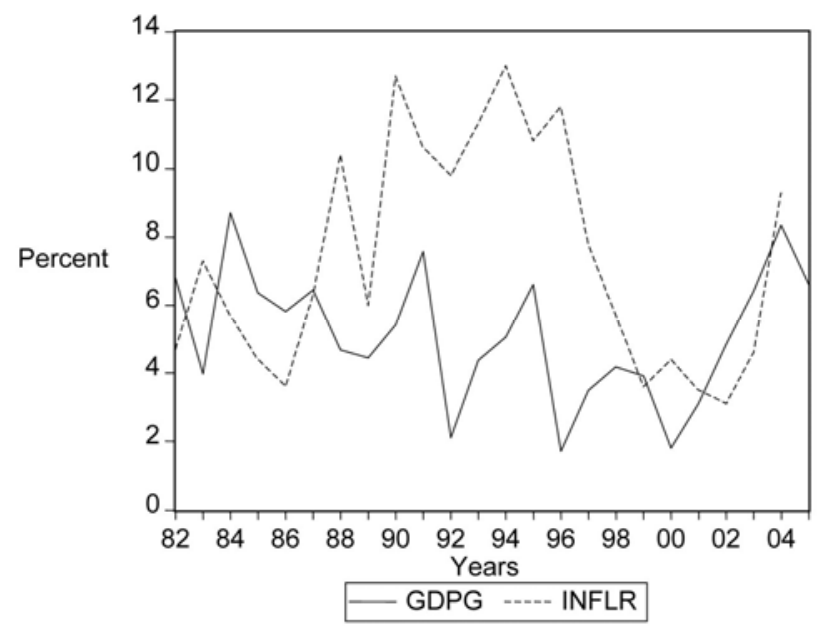

Figure 2. Inflation and GDP Growth Rates (1981-2005)

Source: Pakistan Economic Survey (various issues)

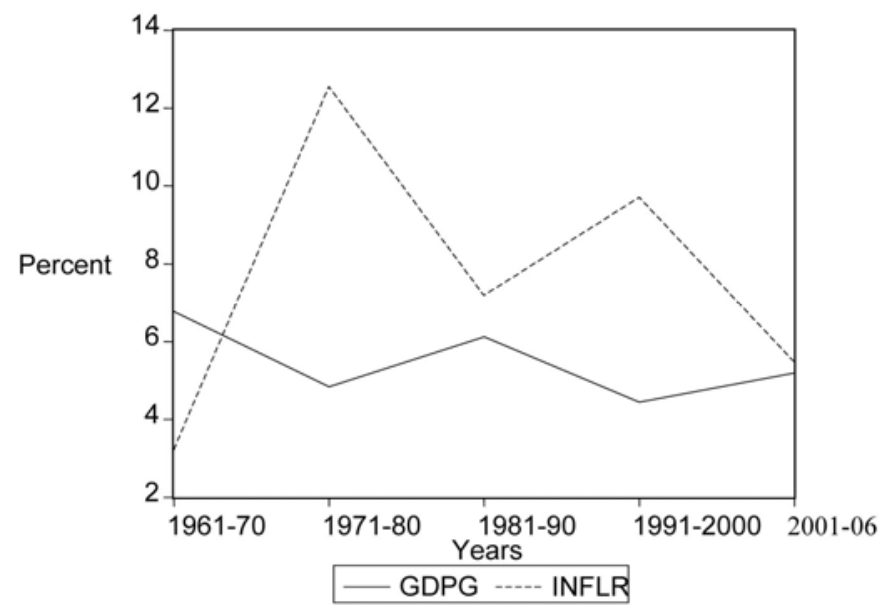

Figure 3. Ten Year Average GDP Growth and Inflation Rates (1961-2006)

Source: Pakistan Economic Survey (various issues)

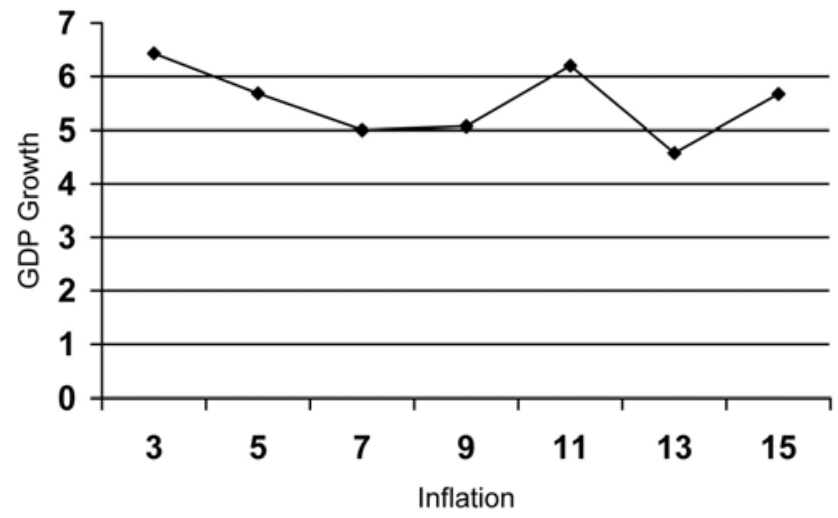

Figure 4. Average GDP Growth and Linear Level of Inflation

Source: Data collected from Pakistan Economic Survey (various issues) 